RESEARCH ARTICLE

\title{
Seed Germination and Seedling Vigor Improvement by Chenopodium (common lambs quarters) leaf extract and Chenopodium Salt Bladders in Rice (Oryza sativa L.)
}

\author{
Vinothini $\mathbf{R}^{1}$, Raja $\mathbf{K}^{\mathbf{1}^{*}}$, Jerlin $\mathbf{R}^{1}$ and Maragatham $\mathbf{S}^{2}$ \\ ${ }^{* 1}$ Department of Seed Science and Technology, Tamil Nadu Agricultural University, Coimbatore-641 003 \\ ${ }^{2}$ Department of Soil Science and Agricultural Chemistry, Tamil Nadu Agricultural University, Coimbatore-641 003
}

Received : $08^{\text {th }}$ April, 2020

Revised : $23^{\text {rd }}$ April, 2020

Revised : $14^{\text {th }}$ May, 2020

Accepted : $29^{\text {th }}$ May, 2020

\begin{abstract}
Chenopodium is a halophyte which absorbs salt from the soil and encrusts in aerial parts particularly in leaves which is known as chenopod salt bladders. Therefore, an experiment was conducted to enhance the seed quality in rice by treating with these bladders. Results showed that significant improvement in seed germination and seedling vigor was recorded in rice. The seeds soaked in Chenopodium leaf extract along with salt bladders @ $0.5 \%$ or salt bladders alone @ $0.6 \%$ for $16 \mathrm{~h}$ at 1:1 (w/v) ratio recorded the highest germination and seedling vigor. It is analyzed that the Chenopodium leaf extract and its salt bladders contains more amount of minerals particularly phosphorous $(0.50 \%, 0.15 \%)$, potassium $(0.83 \%, 1.11 \%)$ nitrogen $(2.52 \%$, 2.21\%), calcium (16.00 ppm, 22.40 ppm), magnesium (190.56 ppm,

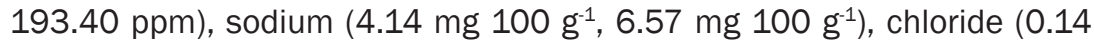
mol. $\left.\mathrm{L}^{-1}, 0.17 \mathrm{~mol}^{-\mathrm{L}^{-1}}\right)$, total phenol $\left(5.00 \mathrm{mg} \mathrm{g}^{-1}, 16.12 \mathrm{mg} \mathrm{g}^{-1}\right)$ and poly phenol oxidase $\left(0.20 \Delta \mathrm{Ag} \mathrm{g}^{-1} \mathrm{~min}^{-1}, 0.10 \Delta \mathrm{Ag}^{-1} \mathrm{~min}^{-1}\right)$, respectively which favoured the enhancement of seed quality in rice.
\end{abstract}

Keywords: Rice; Chenopodium leaf extract; chenopod salt bladders; seed germination; seedling vigor.

\section{INTRODUCTION}

Rice (Oryza sativa L.) is an important food crop of the world, grown in most of the countries. The rice seeds tend to germinate even under anaerobic conditions. Salinity hinders the rice seed germination at early stages such as imbibition, emergence of embryonic tissues, metabolism activation, cell membrane destruction, nutrient imbalance, reduction of enzyme activity and seedling establishment (Rahman et al., 2017; Xiong and Zhu, 2002). On the basis of tolerance ability towards salinity, rice is salt-sensitive crop and hence, growth and yield are affected due to excess salinity (Aslam et al.,1989; Maas and Hoffman, 1977). Even though, some varietal seeds could tolerate these adverse conditions, including treated seeds. In this regard, lambs quarters (Chenopodium album L.) is a halophytic edible weed has the potential to accumulate the salts from the soil and these salts are encrusted through the aerial parts (Flowers, 2015; Reimann and Breckle, 1988; Reimann, 1992). Nevertheless, $\mathrm{Na}^{+}$ions accumulation in vacuole promotes salinity tolerance in plants (Pan et al., 2016). Chenopodium has antifungal (Singh et al., 2011), antibacterial, antioxidant properties and rich of total phenolic contents (Kumar and Kumar, 2009), tannins, saponins, phytic acid, *Corresponding author's e-mail: kraja_sst@rediffmail.com alkaloids and flavanoids (Al-Snafi, 2015). Not only stress tolerance, additionally, it has drought tolerance and defensive mechanism against insect herbivores (LoPresti, 2013). Hence, a study was conducted to assess the effect of these Chenopodium salt bladders on seed germination and seedling vigor in rice by way of seed treatment.

\section{MATERIAL AND METHODS}

The experiment was conducted at the Department of Seed Science and Technology, Tamil Nadu Agricultural University, Coimbatore during 2019 2020. The Chenopodium leaf extract, Chenopodium salt bladders and rice seeds of variety CO 51 constituted as study materials.

\section{Culturing, mineral composition and enzyme activity analysis of Chenopodium}

The mineral composition of the Chenopodium leaves, stems and its salt bladders were analyzed at 30, 60 and 90 days after sowing (DAS), in which, the minerals such as total nitrogen by micro Kjeldahl method using diacid extract (Humphries, 1956), total phosphorous by vanodomolybdate yellow colour method using triple acid extract (Jackson, 1973a), total potassium by flame photometry using triple acid extract (Jackson, 1973a), total calcium

$$
107|4-6| 141
$$


and magnesium by versanate method (Jackson, 1973b) and total phenol (Bray and Thorpe, 1954) and poly phenol oxidase activity (Mayer and Harel, 1979; Mishra, 2012) were estimated and tabulated (Table 1).

\section{Preparation of Chenopodium Leaf extract}

The physiologically active Chenopodium leaf samples were collected at 30 days after sowing (Figure 1). The leaf extract was prepared by grinding the leaves along with the salt bladders in distilled water at different concentrations viz., 0.5, 1, 2, 4, 6,8 and $10 \%$ by $(\mathrm{w} / \mathrm{v})$.

In case of salt bladder extract preparation, the salt bladders on the leaves were scrubbed off and dissolved in few drops of ethanol followed by distilled water. The solutions were prepared at different concentration viz., 0.1, 0.2, 0.3, 0.4, 0.5, 0.6, 0.7, $0.8,0.9$ and $1.0 \%$ by $(\mathrm{w} / \mathrm{v})$.

\section{Chenopodium leaf extract and Chenopodium salt bladders seed invigoration on seed quality}

The experiment was attempted using one-monthold rice seeds with 90 per cent germination. The seeds were soaked in leaf extract and salt bladder extract for $16 \mathrm{~h}$ at equal seed to solution ratio $(\mathrm{w} / \mathrm{v})$ as per the treatments schedule given below and dried back to original moisture content.

\section{Chenopodium leaf extract seed invigoration}

$\mathrm{T}_{0}$ - Control

$\mathrm{T}_{1}$. Soaking in water for $16 \mathrm{~h}$

$\mathrm{T}_{2}$. Soaking in Chenopodium leaf extract @ 0.5\% for $16 \mathrm{~h}$

$\mathrm{T}_{3}$. Soaking in Chenopodium leaf extract @ 1.0\% for $16 \mathrm{~h}$

$\mathrm{T}_{4}$ - Soaking in Chenopodium leaf extract @ 2.0\% for $16 \mathrm{~h}$

$\mathrm{T}_{5}$ Soaking in Chenopodium leaf extract @ 4.0\% for $16 \mathrm{~h}$

$\mathrm{T}_{6}$-Soaking in Chenopodium leaf extract @ 6.0\% for $16 \mathrm{~h}$

$\mathrm{T}_{7}$. Soaking in Chenopodium leaf extract @ 8.0\% for $16 \mathrm{~h}$

$\mathrm{T}_{8}$ - Soaking in Chenopodium leaf extract @ 10.0\% for $16 \mathrm{~h}$

\section{Chenopodium salt bladder seed invigoration}

$\mathrm{T}_{0}$ - Control

$\mathrm{T}_{1}$ - Soaking in water for $16 \mathrm{~h}$

$\mathrm{T}_{2}$ - Soaking in Chenopodium salt bladders @ 0.1\% for $16 \mathrm{~h}$

$\mathrm{T}_{3}$-Soaking in Chenopodium salt bladders @ 0.2\% for $16 \mathrm{~h}$

$\mathrm{T}_{4}$ - Soaking in Chenopodium salt bladders @ 0.3\% for $16 \mathrm{~h}$

$\mathrm{T}_{5}$-Soaking in Chenopodium salt bladders @ 0.4\% for $16 \mathrm{~h}$

$\mathrm{T}_{6}$-Soaking in Chenopodium salt bladders @ 0.5\% for $16 \mathrm{~h}$

$\mathrm{T}_{7}$ - Soaking in Chenopodium salt bladders @ 0.6\% for $16 \mathrm{~h}$

$\mathrm{T}_{8}$-Soaking in Chenopodium salt bladders @ 0.7\% for $16 \mathrm{~h}$
$\mathrm{T}_{9}$ - Soaking in Chenopodium salt bladders @ 0.8\% for $16 \mathrm{~h}$ $\mathrm{T}_{10}$ - Soaking in Chenopodium salt bladders @ 0.9\% for $16 \mathrm{~h}$ $\mathrm{T}_{11}$ - Soaking in Chenopodium salt bladders @ 1.0\% for $16 \mathrm{~h}$

The germination test was conducted using 400 seeds in four replications comprising of 100 seeds each (ISTA, 2013). The speed of germination was calculated using the formula, $X_{1} / Y_{1}+X_{2}-X_{1} / Y_{2}+\ldots \ldots . .+$ $X_{n}\left(X_{n-1}\right) / Y_{n}$, where, $X_{n}$ - number of seeds germinated at $n^{\text {th }}$ count, $Y_{n-}$ number of days from sowing on $\mathrm{n}^{\text {th }}$ count (Maguire, 1962). Shoot and root length were measured from ten randomly selected normal seedlings from the germination test. Seedling dry matter was determined by drying the seedlings in a hot air oven at $85 \pm 2^{\circ} \mathrm{C}$ for $24 \mathrm{~h}$. Vigor index I and II were calculated by multiplying the germination percentage with seedling length and germination percentage with dry matter production, respectively (Abdul-Baki and Anderson, 1973; Reddy and Khan, 2001). In the treated seeds, $\alpha$-amylase (Paul et al., 1970) and poly phenol oxidase activities were also estimated. The experiment was conducted by following completely randomized design (CRD) with four replications.

The data collected were subjected to statistical analysis (Panse and Sukhatme, 1967) and the critical difference values were calculated at $5 \%$ probability level.

\section{RESULTS AND DISCUSSION}

Seed treatment with botanical extract is generally followed as one of the pre-sowing treatment to improve the germination, seedling vigor and stresstolerance.
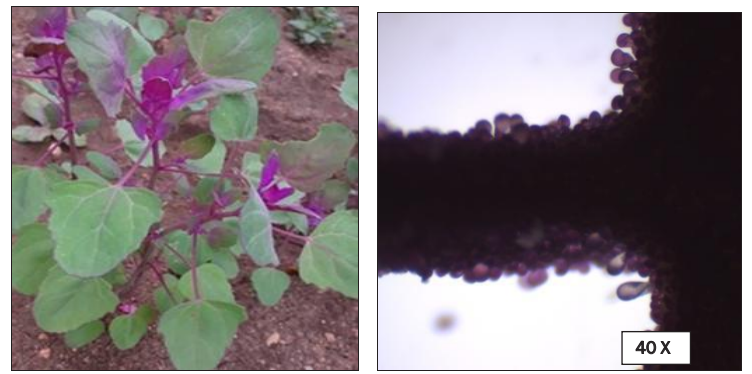

Figure 1. Chenopodium plants with salt bladders and its microscopic view

In the present study, the results showed that the rice seeds soaked in Chenopodium leaf extract @ $0.5 \%$ have recorded the highest germination (97\%) when compared with control (90\%) (Table 2). However, the germination got declined as the concentration increased and recorded the lowest (81\%) at 10 per cent concentration. The improvement in germination might be due to the presence of growth-promoting substances and mineral salts in the Chenopodium leaf extract. This was evidenced by many scientists, who confirmed the presence of growth promoting and bioactive substances viz., 
$\alpha$ - amylase, biosynthesis of gibberellins (Lee et al., 1998; Lee and Kim, 2000; Basra et al., 2005) and synthesis of hydrolytic enzymes during the II phase of the germination. This resulted with early DNA replication (Bray et al., 1989), increased RNA and protein synthesis (Fu et al., 1988), enzyme activation for radical protrusion, antioxidant mechanism for repairing of DNA damage (Fu et al., 1988; Saha et al., 1990; Macovei et al., 2010).

Table 1. Mineral composition and enzyme activity of Chenopodium leaves, stems and its salt bladders

\begin{tabular}{|c|c|c|c|c|}
\hline Minerals & Plant parts & 30 DAS & 60 DAS & 90 DAS \\
\hline \multirow[t]{3}{*}{ Nitrogen (N) (\%) } & Leaves & 2.52 & 2.49 & 1.96 \\
\hline & Stems & 2.30 & 1.34 & 1.06 \\
\hline & Salt bladders & 2.21 & 1.34 & 0.81 \\
\hline \multirow[t]{3}{*}{ Phosphorous (P) (\%) } & Leaves & 0.50 & 0.46 & 0.42 \\
\hline & Stems & 0.37 & 0.43 & 0.20 \\
\hline & Salt bladders & 0.15 & 0.10 & 0.09 \\
\hline \multirow[t]{3}{*}{ Potassium (K) (\%) } & Leaves & 0.83 & 0.79 & 0.75 \\
\hline & Stems & 1.16 & 0.89 & 0.54 \\
\hline & Salt bladders & 1.11 & 1.00 & 0.70 \\
\hline \multirow[t]{3}{*}{ Calcium (Ca) (ppm) } & Leaves & 16.00 & 15.20 & 12.00 \\
\hline & Stems & 13.60 & 10.40 & 10.40 \\
\hline & Salt bladders & 22.40 & 15.20 & 11.20 \\
\hline \multirow[t]{3}{*}{ Magnesium (Mg) (ppm) } & Leaves & 190.56 & 231.84 & 229.44 \\
\hline & Stems & 252.00 & 204.00 & 181.44 \\
\hline & Salt bladders & 193.40 & 217.44 & 204.96 \\
\hline \multirow[t]{3}{*}{ Total phenol (mg/g) } & Leaves & 5.00 & 9.50 & 4.55 \\
\hline & Stems & 1.80 & 4.50 & 2.85 \\
\hline & Salt bladders & 16.12 & 9.00 & 8.50 \\
\hline \multirow{3}{*}{$\begin{array}{l}\text { Polyphenol oxidase } \\
(\Delta \mathrm{A} / \mathrm{g} / \mathrm{min})\end{array}$} & Leaves & 0.20 & 0.10 & 0.05 \\
\hline & Stems & 0.10 & 0.10 & 0.05 \\
\hline & Salt bladders & 0.10 & 0.10 & 0.05 \\
\hline
\end{tabular}

(Values are in dry weight basis) ("DAS - Days after sowing)

Also, the analytical results showed that the Chenopodium leaf contains the minerals such as nitrogen $(2.52 \%)$, phosphorous $(0.50 \%)$, potassium $(0.83 \%)$, calcium $(16 \mathrm{ppm})$ magnesium $(190.56$ ppm), total phenol (5.00 $\left.\mathrm{mg} \mathrm{g}^{-1}\right)$ and poly phenol oxidase $\left(0.20 \Delta \mathrm{A} \mathrm{g}^{-1} \mathrm{~min}^{-1}\right)$ which were higher at early stages of plant growth i.e. at 30 days after sowing when compared with 60 and 90 days old plants (Table 1).

Table 2. Effect of Chenopodium leaf extract on seed germination and seedling vigor in rice

\begin{tabular}{|c|c|c|c|c|c|}
\hline Treatments & $\begin{array}{c}\text { Germination } \\
(\%)\end{array}$ & $\begin{array}{l}\text { Root length } \\
\text { (cm) }\end{array}$ & $\begin{array}{l}\text { Shoot length } \\
(\mathrm{cm})\end{array}$ & $\begin{array}{l}\text { Dry matter production } \\
\text { (mg/10 seedlings) }\end{array}$ & $\begin{array}{c}\text { Vigor } \\
\text { Index (II) }\end{array}$ \\
\hline $\mathrm{T}_{0}$. Control & $90(71.6)$ & 16.20 & 6.14 & 64.25 & 5.78 \\
\hline $\mathrm{T}_{1}$. Soaking in water for $16 \mathrm{~h}$ & $92(73.6)$ & 17.30 & 6.50 & 77.73 & 7.15 \\
\hline $\mathrm{T}_{2}$. Soaking in Chenopodium leaf extract @ 0.5\% for $16 \mathrm{~h}$ & $97(80.0)$ & 18.50 & 7.60 & 84.55 & 8.20 \\
\hline $\mathrm{T}_{3}$. Soaking in Chenopodium leaf extract @ 1.0\% for $16 \mathrm{~h}$ & $94(75.8)$ & 17.80 & 7.26 & 76.13 & 7.16 \\
\hline $\mathrm{T}_{4}$. Soaking in Chenopodium leaf extract @ 2.0\% for $16 \mathrm{~h}$ & $90(71.6)$ & 17.65 & 7.05 & 69.88 & 6.29 \\
\hline $\mathrm{T}_{5}$. Soaking in Chenopodium leaf extract @ $4.0 \%$ for $16 \mathrm{~h}$ & $88(69.7)$ & 17.41 & 6.64 & 64.05 & 5.64 \\
\hline $\mathrm{T}_{6}$. Soaking in Chenopodium leaf extract @ 6.0\% for $16 \mathrm{~h}$ & $85(67.2)$ & 17.20 & 6.32 & 62.70 & 5.33 \\
\hline $\mathrm{T}_{7}$. Soaking in Chenopodium leaf extract @ 8.0\% for $16 \mathrm{~h}$ & $83(65.6)$ & 16.91 & 6.20 & 61.75 & 5.13 \\
\hline $\mathrm{T}_{8}$ Soaking in Chenopodium leaf extract @ 10.0\% for $16 \mathrm{~h}$ & $81(64.2)$ & 16.10 & 6.03 & 60.83 & 4.93 \\
\hline Mean & $71(57.4)$ & 17.23 & 6.64 & 69.10 & 6.17 \\
\hline SEd & 1.55 & 0.20 & 0.09 & 0.81 & 0.07 \\
\hline$C D(P=0.05)$ & 3.18 & 0.41 & 0.18 & 1.66 & 0.15 \\
\hline
\end{tabular}


Calcium may act as co-factor for enzymes for improvement in germination and vigor (Christansen and Foy, 1979). However, presence of higher amount of minerals particularly the sodium salts have resulted with the deleterious effect on seed germination when the seeds were soaked in higher concentrations.

Table 3. Effect of Chenopodium salt bladder on seed germination and seedling vigor in rice

\begin{tabular}{|c|c|c|c|c|c|}
\hline Treatments & $\begin{array}{c}\text { Germination } \\
\text { (\%) }\end{array}$ & $\begin{array}{l}\text { Root length } \\
(\mathrm{cm})\end{array}$ & $\begin{array}{l}\text { Shoot } \\
\text { length } \\
(\mathrm{cm})\end{array}$ & $\begin{array}{c}\text { Dry matter } \\
\text { production } \\
\text { (mg/10 seedlings) }\end{array}$ & $\begin{array}{c}\text { Vigor } \\
\text { Index II }\end{array}$ \\
\hline $\mathrm{T}_{0}$. Control & $90(71.57)$ & 16.4 & 6.0 & 67.55 & 6.08 \\
\hline $\mathrm{T}_{1}$. Soaking in water for $16 \mathrm{~h}$ & $92(73.57)$ & 16.9 & 6.2 & 65.85 & 6.06 \\
\hline $\mathrm{T}_{2}$. Soaking in Chenopodium salt bladders @ 0.1\% for $16 \mathrm{~h}$ & $86(68.03)$ & 16.6 & 5.9 & 66.90 & 5.75 \\
\hline $\mathrm{T}_{3}$. Soaking in Chenopodium salt bladders @ 0.2\% for $16 \mathrm{~h}$ & 89 (70.63) & 17.2 & 6.0 & 71.65 & 6.38 \\
\hline $\mathrm{T}_{4}$. Soaking in Chenopodium salt bladders @ 0.3\% for $16 \mathrm{~h}$ & $87(68.87)$ & 17.4 & 6.4 & 67.51 & 5.87 \\
\hline $\mathrm{T}_{5}$. Soaking in Chenopodium salt bladders @ 0.4\% for $16 \mathrm{~h}$ & $90(71.57)$ & 17.0 & 6.3 & 62.80 & 5.65 \\
\hline $\mathrm{T}_{6}$. Soaking in Chenopodium salt bladders @ 0.5\% for $16 \mathrm{~h}$ & $92(73.57)$ & 17.4 & 6.7 & 62.63 & 5.76 \\
\hline $\mathrm{T}_{7}$. Soaking in Chenopodium salt bladders @ 0.6\% for $16 \mathrm{~h}$ & $98(81.87)$ & 18.7 & 7.2 & 74.13 & 7.26 \\
\hline $\mathrm{T}_{8}$. Soaking in Chenopodium salt bladders @ 0.7\% for $16 \mathrm{~h}$ & $92(73.57)$ & 16.5 & 6.7 & 67.40 & 6.20 \\
\hline $\mathrm{T}_{9}$. Soaking in Chenopodium salt bladders @ 0.8\% for $16 \mathrm{~h}$ & $90(71.57)$ & 17.1 & 6.3 & 66.85 & 6.02 \\
\hline $\mathrm{T}_{10}$. Soaking in Chenopodium salt bladders @ 0.9\% for 16 h & $87(68.87)$ & 17.4 & 6.0 & 67.00 & 5.83 \\
\hline $\mathrm{T}_{11}$. Soaking in Chenopodium salt bladders @ 1.0\% for $16 \mathrm{~h}$ & $85(67.21)$ & 17.0 & 5.9 & 66.93 & 5.69 \\
\hline Mean & $72(58.05)$ & 17.1 & 6.30 & 67.27 & 6.05 \\
\hline SEd & 1.76 & 0.23 & 0.09 & 0.94 & 0.08 \\
\hline$C D(P=0.05)$ & 3.58 & 0.46 & 0.18 & 1.91 & 0.17 \\
\hline
\end{tabular}

Similarly, the speed of germination was maximum (9.0) when the seeds were soaked in Chenopodium leaf extract @ 0.5\% (Figure 2).

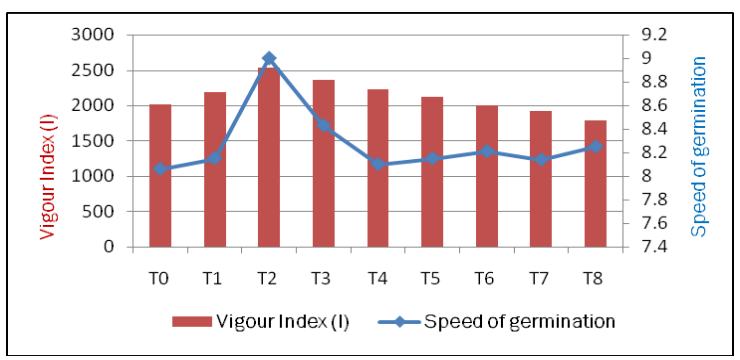

Figure 2. Effect of Chenopodium leaf extract on speed of germination and seedling vigor index (I) in rice

Root length $(18.50 \mathrm{~cm})$, shoot length $(7.60 \mathrm{~cm})$ and seedling dry matter (84.55 mg / 10 seedlings) were also higher at $0.5 \%$ concentration (Table 2 ).

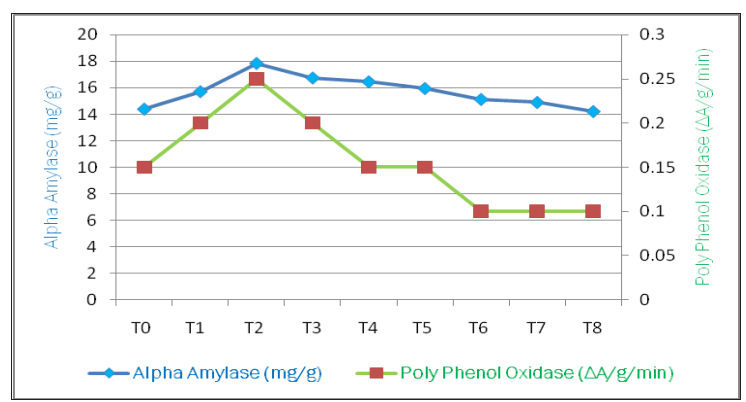

Figure 3. Effect of Chenopodium leaf extract on $\alpha$-amylase and poly phenol oxidase in rice

Computed vigor index I (2531) and II (8.20) were higher when the rice seeds soaked in Chenopodium leaf extract at $0.5 \%$ concentration. This vigor improvement is mainly due to the greater synthesis of growth hormones, ATP availability and faster embryo growth (Dahal et al., 1990) due to leaf extract soaking. Similar findings of germination and vigor improvement by soaking the seeds in leaf extracts viz., Prosopis, neem, moringa and Pongamia were studied earlier in paddy (Shakuntala et al., 2012; Ahmed et al., 2013; Gunasekar et al., 2017; Kamaraj et al., 2019). The presence of flavonoids, tannins, saponins, phenolic compounds and glycosides in Prosopis and Pongamia leaf extracts would have triggered the germination (Rathinavel et al., 2000; Behera et al., 2012). In Chenopodium leaf extract @ 0.5\% treated seeds, $\alpha$-amylase (17.84 mg $\left.\mathrm{g}^{-1}\right)$ and poly phenol oxidase $\left(0.25 \Delta \mathrm{A} . \mathrm{g}^{-1} \cdot \mathrm{min}^{-1}\right)$ activities recorded were also maximum (Figure 3 ).

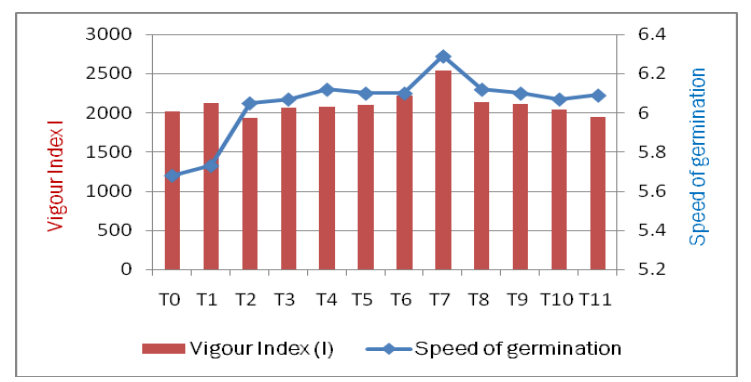

Figure 4. Effect of Chenopodium salt bladders on speed germination and vigor index $(\mathrm{I})$ in rice

Regarding Chenopodium salt bladders, the highest germination (98\%) was observed at 0.6 per cent as compared to control (90\%) (Table 3). This might be due to the presence of minerals in salt 
bladders such as nitrogen (2.21\%), phosphorous (0.15\%), potassium (1.11\%), calcium (22.40 ppm), magnesium (193.40 ppm), sodium (6.57 mg $100 \mathrm{~g} \mathrm{~g}^{-1}$ ), chloride $\left(0.17 \mathrm{~mol}^{-1}\right)$, total phenol (16.12 $\left.\mathrm{mg} \mathrm{g}^{-1}\right)$ and polyphenol oxidase $\left(0.10 \Delta \mathrm{A} \mathrm{g}^{-1} \mathrm{~min}^{-1}\right)$ at early stage of plants (30 DAS). However, the reduction in germination was noticed at higher concentrations. This might be due to the higher concentrations of $\mathrm{Na}^{+}$and $\mathrm{Cl}^{-}$ions in salt bladders. Similarly, speed of germination (6.29), root length $(18.7 \mathrm{~cm})$, shoot length $(7.2 \mathrm{~cm})$ and dry matter $(74.13 \mathrm{mg} / 10$ seedlings) were maximum in the seeds soaked in Chenopodium salt bladders @ 0.6\% concentration (Table 3). Vigor index I (2538) and II (7.26) were also higher at this concentration (Figure 4).

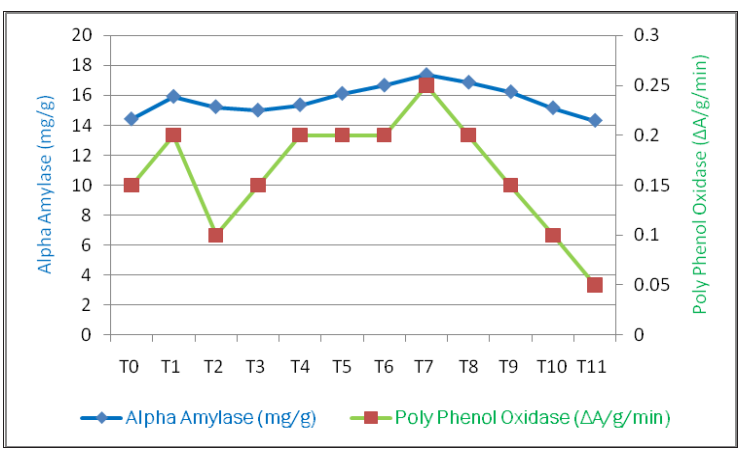

Figure 5. Effect of Chenopodium salt bladders on $\alpha$-amylase and poly phenol oxidase in rice

Alpha amylase (17.38 $\left.\mathrm{mg}^{-1} \mathrm{~g}^{-1}\right)$ and poly phenol oxidase $\left(0.25 \Delta \mathrm{A} . \mathrm{g}^{-1} \cdot \mathrm{min}^{-1}\right)$ activities were also higher in the seeds soaked in Chenopodium salt bladders @ 0.6\% (Figure 5). Similar studies were also carried out earlier by the effect of $\mathrm{NaCl}$ on seed germination and seedling vigor (Jeannette et al., 2002; Mavi et al., 2006).

\section{CONCLUSION}

It is concluded that the Chenopodium leaf extract at 0.5 per cent or Chenopodium salt bladders at 0.6 per cent concentration have beneficial effect on improvement of seed germination and seedling vigor in rice. Further study is needed on the effect of these salt bladders for the induction of salt tolerance in other crop seeds.

\section{REFERENCES}

Abdul-Baki, A.A. and J.D. Anderson. 1973. Vigor determination in soybean seed by multiple criteria 1. Crop Sci., 13(6): 630-633.

Ahmed, M., Hossain, M., Hassan, K. and C. K. Dash. 2013. Efficacy of different plant extract on reducing seed borne infection and increasing germination of collected rice seed sample. Universal J. Plant Sci., 1(3): 66-73.

Al-Snafi, A.E. 2015. The chemical constituents and pharmacological effects of Chenopodium album - An overview. Intl. J. Pharma. Screening Methods., 5(1): 10-17.
Aslam, M., Qureshi, R. H., Ahmad, N. and S. Muhammad. 1989. Salinity tolerance of rice (Oryza sativa L.): Morphological studies. Pak. J. Agric. Sci., 150: 99-107.

Basra, S.M.A., Farooq, M. and R. Tabassum. 2005. Physiological and biochemical aspects of seed vigour enhancement treatments in fine rice (Oryza sativa L.). Seed Sci. \& Technol., 33: 25-29.

Behera, S., Manohar Babu, S. and Y. Roja Ramani. 2012. Phytochemical investigation and study on antioxidant properties of Pongamia pinnata hydroalcoholic leaf extract. Plant Sci. Feed., 2(5):74-78.

Bray, H.G. and W.V. Thorpe. 1954. Estimation of phenols. Methods of Biochemical Analysis., 1: 27-52.

Bray, C. M., Davison, P. A., Ashraf, M. and M. R. Taylor. 1989. Biochemical events during osmo priming of leek seed. Ann. Appl. Biol., 102: 185-193.

Christansen, M.N. and C. D. Foy. 1979. Fate and function of calcium in tissue. Common. Soil Sci. Pl. Anal., 10: $427-442$.

Dahal, P., Bradford, K.J. and R. A. Jones. 1990. Effects of priming and endosperm integrity on germination rates of tomato genotypes. I. Germination at suboptimal temperature. J. Exp. Bot., 41: 14311439.

Flowers, T.J., Munns, R. and T.D. Colmer. 2015. Sodium chloride toxicity and the cellular basis of salt tolerance in halophytes. Ann. Bot., 115: 419-431.

Fu, J.R., Lu, S. H., Chen, R. Z. B., Zhang, Z., Liu, Z. S. and D.Y. Cai.1988. Osmoconditioning of peanut (Arachis hypogaea L.) seed with PEG to improve vigour and some biochemical activities. Seed Sci. Technol., 16: 197-212.

Gunasekar, J., Kamaraj, A. and S. Padmavathi. 2017. Effect of pre sowing seed priming treatment using botanical leaf extract on growth and yield characters in black gram (Vigna mungo [L.] Hepper) cv. CO 6. Plant Arch., 17(2): 1013-1016.

Humphries, E.C. 1956. Mineral components and ash analysis. Moderne Methoden der Pflanzenanalyse/ Modern Methods of Plant Analysis., 468-502.

ISTA. 2013. International Rules for Seed Testing. International Seed Testing Association,Bassorsdorf, Switzerland. 27.

Jackson, M.L. 1973a. Vanadomolybdo phosphoric yellow color method for determination of phosphorus. Soil Chemical Analysis. Prentice Hall of India Pvt. Ltd, New Delhi. 151-154.

Jackson, M.L. 1973b. Soil Chemical Analysis, (2nd Indian Print) Prentice-Hall of India Pvt. Ltd. New Delhi.

Jeannette, S., Jimenez, B., Graig, R. and J. Lynch. 2002. Salinity tolerance of Phaseolus species during germination and early seedling growth. Seed Physiol. Production \& Technology., 42: 1584-1594.

Kamaraj, A., Padmavathi, S., Ezhilkumar, S. and P. Satheeshkumar. 2019. Enhancement on seedling morphological and physiological characteristics of green gram seeds through presowing seed treatment. J. Pharmaco. Phytochem., SP2: 454458. 
Kumar, S. and D. Kumar. 2009. Antioxidant and free radical scavenging activities of edible weeds. Afr. J. Food, Agric. Nutr. Dev., 9(5): 1174-1190.

Lee, S., Kim, J.H., Hong, S.B., Yun, S.H. and E. H. Park. 1998. Priming effect of rice seeds on seedling establishment under adverse soil conditions. Korean J. Crop Sci., 43:194-198.

Lee, S. S. and J. H. Kim. 2000. Total sugars, alpha amylase activity, and germination after priming of normal and aged rice seeds. Korean J. Crop Sci., 45(2): 108-111.

LoPresti, E. F. 2014. Chenopod salt bladders deter insect herbivores. Oecologia., 174(3): 921-930.

Maas, E. V., and Hoffman, G. J. 1977. Crop salt tolerance-current assessment. Journal of the Irrigation and Drainage Division., 103(2): 115-134.

Macovei, A., Balestrazzi, A., Confalonieri, M. and D. Carbonera. 2010. The Tdp/ (Tyrosyl-DNA phosphodiesterase) gene family in barrel medic (Medicago truncatula Gaertn.): bioinformatic investigation and expression profiles in response to copper and PEG-mediated stress. Planta., 232: 393-407.

Maguire, J.D. 1962. Speed of germination-Aid in selection and evaluation for seedling emergence and vigor 1. Crop Sci., 2(2): 176-177.

Mavi, K., Ermis, S. and I. Demir. 2006. The effect of priming on tomato rootstock seeds in relation to seedling growth. Asian J. PI. Sci., 5(6): 940-947.

Mayer, A.M. and Harel, E. 1979. Polyphenol oxidases in plants. Phytochemistry., 18(2): 193-215.

Mishra, B.B., Gautam, S. and A. Sharma. 2012. Purification and characterisation of polyphenol oxidase (PPO) from eggplant (Solanum melongena). Food chemistry., 134(4): 1855-1861.

Paul, A. K., Mukherji, S. and S. M. Sircar. 1970. Metabolic changes in rice seeds during storage. Indian J. Agric. Sci.,40(12): 1031-1036.
Pan, Y.Q., Guo, H., Wang, S.M., Zhao, B., Zhang, J. L., Qing, M., Yin, H. J. and A. K. Bao. 2016. The photosynthesis, $\mathrm{Na}+/ \mathrm{K}+$ homeostasis and osmotic adjustment of Atriplex canescens in response to salinity. Frontiers in Plant Sci., 7: 848.

Panse, V.G. and P.V. Sukhatme. 1967. Statistical Method for Agricultural Worker, ICAR Publication, New Delhi.

Rahman, A., Nahar, K., Al Mahmud, J., Hasanuzzaman, M., Hossain, M. S. and M. Fujita. 2017. Salt stress tolerance in rice: emerging role of exogenous phytoprotectants.Advances in International Rice Research., 9:139-174.

Rathinavel, K. and C. Dharmalingam. 1999. Effect of seed pelleting on elite seedling production in cotton cv. MCU7 (Gossypium hirsutum L.). Crop Res., 18(1): 137-141.

Reimann, C. and S.W. Breckle. 1988. Salt secretion in some Chenopodium species. Flora., 180(3-4): 289-296.

Reimann, C. 1992 . Sodium exclusion by Chenopodium species. J. Exp. Bot., 43(4): 503- 510.

Reddy, Y.T.N. and M.M. Khan. 2001. Effect of osmopriming on germination, seedling growth and vigour of khirni (Mimusops hexandra) seeds. Seed Res., 29(1): 24-27.

Saha, R., Mandal, A. K. and R. N. Basu. 1990. Physiology of seed invigoration treatments in soybean (Glycine max L.). Seed Sci. \& Technol., 18: 269-276.

Shakuntala, N.M., Vasudevan, S.N., Patil, S.B., Doddagoudar, S.R., Mathad, R.C., Macha, S.I. and A.G. Vijaykumar. 2012. Organic biopriming on seed vigour inducing enzyme in paddy - An alternative to inorganics. The Ecoscan., 1: 251-257.

Singh, K.P., Dwevedi, A.K. and G. Dhakre. 2011. Evaluation of antibacterial activities of Chenopodium album (L.). Intl. J. Appl. Biol. Pharma. Technol., 2(3): 398-401.

Xiong, L. and J.K. Zhu. 2002. Molecular and genetic aspects of plant responses to osmotic stress. Plant, Cell \& Environment., 25(2): 131-139. 